\title{
Człowieczy los...
}

Omówienie serii wydawniczej „Świadectwa xx wieku” wydawanej w ramach „Biblioteki Zesłańca” przez

Zarząd Główny Polskiego Towarzystwa Ludoznawczego we Wrocławiu*

DOI: $10.26774 /$ wrhm.315

\section{Wiktoria Kudela-Świątek}

[Uniwersytet Pedagogiczny im. KEN w Krakowie]

(D) https://orcid.org/0000-0001-9559-0784

* Kolekcja sybiracka Archiwum Naukowego Polskiego Towarzystwa Ludoznawczego we Wrocławiu: bibliografia komentowana, oprac. M. Ruchniewicz, („Biblioteka Zesłańca, Świadectwa xx wieku”, t. 1) Wrocław 2019; Jan Konopielko, Wspomnienia 19061956, oprac. P. Cichoracki, M. Jakimowicz, M. Ruchniewicz, („Biblioteka Zesłańca, Świadectwa xx wieku", t. 2) Wrocław 2020; Jan Wojdyła, Wspomnienia, wstęp i oprac. P. Cichoracki, („Biblioteka Zesłańca, Świadectwa xx wieku”, t. 3) Wrocław 2020; Ewa Sobota-Grün, Podróż w nieznane, wstęp i oprac. M. Ruchniewicz, („Biblioteka Zesłańca, Świadectwa xx wieku", t. 4) Wrocław 2020; Henryk Łęczycki, Strzępy wspomnień 1939-1947, wstęp i oprac. M. Jakimowicz, („Biblioteka Zesłańca, Świadectwa xx wieku", t. 5) Wrocław 2020. 
Edycje źródłowe są niezwykle wymagającym przedsięwzięciem dla redaktorów, którzy podejmują się tego zadania. Jest to, jak na współczesne czasy, niespotykany przykład altruizmu naukowego, który jest działaniem na rzecz środowiska, rzadziej na rzecz własnego dorobku naukowego. Wybitny polski badacz i wydawca źródeł, Stefan Kieniewicz, swego czasu napisał, że „edytorstwo jest przede wszystkim służbą. Książki naukowe piszemy i publikujemy na ogół dla własnej satysfakcji; źródła wydajemy po to, by z nich korzystał kto inny. Ale też edycja źródłowa, jeśli rzetelnie przygotowana, zachowuje przydatność swą o wiele dłużej aniżeli monografia, a znacznie jeszcze dłużej niż podręcznik"1. Jest to zatem istotna gałąź w obrębie nauk historycznych, której rezultaty są niezwykle trwałe, mająca dużą wartość dla historiografii. W innym miejscu cytowanego eseju Kieniewicz dodaje nadto, że edytorstwo nie jest wdzięcznym zawodem, bowiem „nie przynosi poklasku, nie bardzo liczy się w dorobku naukowym, nie bywa też opłacane we właściwym stosunku do włożonego trudu. Wymaga zaś rozległej wiedzy i pracowitości. Jest sprawą bardzo ważną dla naszego zawodu, abyśmy własną naszą zawodową umiejętność zechcieli przekazywać następnemu pokoleniu"2. Od początku lat 9o. xx w., kiedy Kieniewicz spisywał swoje refleksje nad własną działalnością na tej niwie, niewiele się zmieniło. Wydawanie źródeł nadal jest dziedziną wymagającą ogromnej wiedzy, nakładu pracy i środków, jednakże efekty tej pracy zostaną docenione dopiero przez kolejne pokolenia badaczy i czytelników (jeśli w ogóle tak się stanie). Dlatego każda kolejna inicjatywa edytorska zasługuje na przyjrzenie się jej bliżej.

Przedmiotem mojej refleksji jest nowa seria wydawnicza pt. „Świadectwa xx wieku” w ramach „Biblioteki Zesłańca” wydawanej przez Zarząd Główny Polskiego Towarzystwa Ludoznawczego we Wrocławiu. Wszystkie recenzowane publikacje są edycjami krytycznymi wspomnień pochodzących z Kolekcji sybirackiej tegoż Archiwum Naukowego. Seria ta w swoim założeniu ma zmienić dotychczasowe wyobrażenie na temat pamiętników Sybiraków i ich doświadczenia wojny. $Z$ racji tego, że moje omówienie dotyczy kilkutomowego przedsięwzięcia naukowego, podzieliłam je na kilka wątków. Na początku chciałabym opisać kolekcję archiwalną, z której pochodzą wspomnienia publikowane w ramach omawianej serii, następnie pokrótce przedstawię sylwetkę każdego z autorów opublikowanych w ramach analizowanej serii pamiętników oraz treść opublikowanego pamiętnika. Na końcu zaś chciałabym omówić opracowaną przez zespół redakcyjny instrukcję wydawniczą i jej realizację na przykładzie omawianej serii.

1 S. Kieniewicz, Z doświadczeń edytora źródeł historycznych, „Archeion”, т. 87 (1990), s. 123.

2 Ibidem, s. 130. 
W pierwszej kolejności należy zwrócić uwagę na to, że kolekcja AN zG PTL jest jednym z największych zbiorów tego typu w Polsce poza Archiwum Wschodnim Ośrodka KARTA w Warszawie ${ }^{3}$. Ośrodek wrocławski, począwszy od lat 9o. xx w. gromadzi materiały dotyczące losów Polaków na Wschodzie w xx w., ze szczególnym naciskiem na okres II wojny światowej oraz doświadczenie masowych deportacji, zsyłek i wypędzeń w głąb Związku Radzieckiego. Obecnie zbiór liczy niemal tysiąc wspomnień rękopiśmiennych.

Początkiem zbiorów były materiały zabrane na przełomie lat 80. i 90. xx w. w wyniku konkursu pamiętnikarskiego ogłoszonego w styczniu 1988 r. przez Zarząd Główny PTL oraz redakcję dwumiesięcznika „Literatura Ludowa”, wydawanego przez Towarzystwo. Był to konkurs otwarty na wspomnienia i materiały dotyczące pobytu Polaków na Syberii, Dalekim Wschodzie, w Kazachstanie oraz na innych terenach Związku Radzieckiego w latach 1939-1956. Zainteresowanie społeczne tym przedsięwzięciem przerosło oczekiwania organizatorów, a idea konkursu rezonowała społecznie pomimo upływu lat od jego zamknięcia. Wielu Sybiraków zaczęło wysyłać na adres PTL swoje wspomnienia i materiały z rodzinnych archiwów.

Zważywszy na wyjątkowy charakter zgromadzonych źródeł i wagę tych wspomnień dla potomnych, poza opublikowaniem kilku wyróżnionych we wspomnianym konkursie prac na łamach „Literatury Ludowej”, PTL zdecydował się także na powołanie nowej serii wydawniczej pt. „Biblioteka Zesłańca”. Działa ona z dużym powodzeniem od $1991 \mathrm{r}$. i wydała dotąd prawie 30 tomów wspomnień i opracowań historycznych, w których przedstawiono życie zesłańców w Kazachstanie, na Syberii, w tzw. obwodzie archangielskim, na Dalekim Wschodzie i w innych rejonach byłego zSRR. Jednakże tylko $20 \mathrm{z}$ nich zawiera wspomnienia zesłańców z czasów II wojny światowej, pozostałe publikacje mają nieco inny zakres tematyczny. Seria ta udostępniła niezwykle cenne świadectwa traumy deportacji całej generacji Polaków, stanowiące nie tylko ważne źródło historyczne, lecz także mające ogromny potencjał dla wychowania obywatelskiego następnych pokoleń, dla których pamięć o tym doświadczeniu jest jedynie elementem dziedzictwa historycznego. Warto jednak podkreślić, że ta inicjatywa wydawnicza nie wyczerpała wszystkich możliwości, jakie daje materiał zgromadzony w Archiwum Naukowym zG PTL we Wrocławiu'. Kolekcja ta bowiem zawiera

3 A. Zapalec, Wspomnienia Sybiraków jako źródło historyczne w badaniach nad procesem deportacji obywateli polskich w głąb zsRS 1940-1941, [w:] Pamiętniki, dzienniki i relacje jako źródła do badań historycznych, red. K. Karolczak, Kraków 2011, s. 245-261.

4 Tylko część wydanych w ramach serii tomów stanowią maszynopisy nagrodzone we wspomnianym konkursie pamiętnikarskim i zgromadzone w Archiwum Naukowym zG PTL. Więcej o tej serii, zob.: A. Kuczyński, Losy Sybiraków w książkach opowiedziane: dzieje „Biblioteki Zesłańca” i recepcja jej wydawnictw, „Niepodległość i Pamięć”, t. 5/2 (11) (1998), s. 265-279. 
wiele materiałów wartych publikacji i udostępnienia szerszemu gronu nie tylko badaczy, lecz także wszystkich zainteresowanych historią xx w. Nie dziwi przy tym fakt, że te materiały zostały już częściowo wykorzystane w wielu pracach magisterskich, doktorskich oraz rozmaitych monografiach naukowych, powstających nie tylko we wrocławskim ośrodku naukowym. Opublikowanie w całości wybranych wspomnień pozwoliłoby jednakże rozpropagować całe archiwum na znacznie większą skalę niż dotychczas. Taka idea przyświecała kierownikowi projektu, dr. hab. Małgorzacie Ruchniewicz, prof. uwr, oraz jej zespołowi (dr hab. Piotrowi Cichorackiemu, prof. uwr, i dr Marcelinie Jakimowicz z URz) w realizowanym od roku 2018 projekcie edycji źródłowej tej kolekcji w ramach Narodowego Programu Rozwoju Humanistyki.

Zasadniczym celem wspomnianego projektu było zatem powołanie podserii wydawniczej, zatytułowanej „Świadectwa xx wieku”, w ramach której czytelnicy otrzymają publikacje w formie papierowej i e-booki. W zamyśle redaktorów jest wydanie źródeł wspomnieniowych w nowoczesnym naukowym opracowaniu (planowane jest wydanie 15-20 tomów) poprzez opatrzenie ich wstępem przybliżającym ich autorów, kontekst historyczny oraz wartość i specyfikę tekstu, a także wyposażenie źródeł w przypisy, materiał ilustracyjny, mapy i indeksy. Zamiarem zespołu projektowego jest publikacja tekstów prezentujących różne aspekty polskich losów na Wschodzie, zarówno w niepodległym państwie - na Kresach II RP (życie codzienne, relacje ze społecznościami lokalnymi, praca społeczna), jak i po wybuchu II wojny światowej (doświadczenie zesłańców, więźniów i łagierników po 1939 r., życie codzienne podczas obu okupacji i w pierwszych latach po II wojnie światowej, czy działalność polskiego podziemia na Kresach Wschodnich). Dodatkowym celem projektu było przygotowanie, na podstawie opracowanej już bibliografii komentowanej $j^{5}$, bazy, pozwalającej użytkownikowi na łatwe wyszukiwanie on-line jednostek archiwalnych w ramach całej kolekcji ${ }^{6}$.

Ponadto autorzy projektu pragnęli spopularyzować wśród badaczy, studentów, dziennikarzy i pasjonatów historii wrocławskiej kolekcji, stanowiącej największy zasób materiałów o losach Polaków na Wschodzie po 1939 r. na terenie zachodniej Polski. Jak sądzę, ambicją zespołu projektowego jest także rozszerzenie grupy docelowej na badaczy spoza Polski, stąd pomysł na przygotowanie anglojęzycznej wersji strony internetowej projektu?. Dzięki temu wszystkiemu mamy do czynienia z adekwatną do współczesnych potrzeb rynku książki naukowej propozycję, której warto przyjrzeć się szczegółowo. Dotychczas w serii ukazały się wspomnienia czterech autorów, które przedtem nie były publikowane.

6 Więcej zob.: http://ptl.info.pl/zbiory-archiwalne/zasoby-opracowane/192,Wspomnienia-Sybirakow.html (dostęp: 3 xir 2021 r.).

7 Więcej zob.: http://bibliotekazeslancanowa.pl/ (dostęp: 3 XıI 2021 r.). 
Serię inaugurują wspomnienia Jana Konopielki (1906-1985) z lat 1906-1956 . Autor pochodził z wielodzietnej rodziny chłopskiej z Wileńszczyzny. Mimo biedy, z ogromnym uporem dążył do tego, by zdobyć zawód nauczyciela. Kształcił się w seminarium nauczycielskim w Borunach (1924 r.) i w Wilnie, gdzie w 1930 r. zdał maturę. Pracował jako nauczyciel w rodzinnym powiecie, gdzie cieszył się szacunkiem za osiągnięty własnymi siłami w bardzo trudnych warunkach awans społeczny. Przed wojną ukończył Wyższy Kurs Nauczycielski w Warszawie i objął posadę dyrektora sześcioklasowej szkoły w Sukniewiczach. Założył też rodzinę. W czasie II wojny światowej przeniósł się do pobliskiego miasteczka Smorgonie, gdzie wraz z rodziną przetrwał całą okupację. Po ponownym wkroczeniu armii sowieckiej na Wileńszczyznę, w końcu sierpnia 1944 r. Konopielko został aresztowany przez NKwD i osadzony w więzieniu w Wilejce. Był oskarżony o kolaborację z Niemcami i skazany na 10 lat pobytu w poprawczym obozie pracy na północy zSRR (od 1945 w Mołotowsku, obecnie Siewerodwińsk w Rosji). W 1948 r. wraz ze współwięźniami został przeniesiony do obozu dla więźniów politycznych w okolicach miasta Tajszet w obwodzie irkuckim. Pracował przy wyrębie tajgi, a później - ze względu na pogarszający się stan zdrowia - jako strażak, pracownik stołówki i magazynier w łagrze (kaptiorszczik). Następnie przebywał w obozach nad Zatoką Wanino oraz w obozie w okolicy Żezkazganu w Kazachstanie. W sierpniu 1954 r. został zwolniony z obozu i skierowany na osiedlenie się w sowchozie im. E. Thälmanna w obwodzie Karaganda (Kazachstan). Przez cały ten czas poszukiwał kontaktu z rodziną zamieszkującą w PRL i na Sowieckiej Białorusi. W połowie lat 50. xx w. zezwolono mu na osiedlenie się w białoruskiej Smorgoni, gdzie spotkał się ze swoim rodzeństwem. Do Polski repatriował się wraz z rodziną w $1956 \mathrm{r}$. i zamieszkał wraz z żoną i dziećmi w Lidzbarku Warmińskim. Tam Konopielko powrócił do pracy zawodowej jako nauczyciel języka rosyjskiego w Szkole Zawodowej, a równocześnie pełnił funkcję kierownika szkolnego internatu. Angażował się w życie kulturalne i społeczne, a wolne chwilę dzielił między życie rodzinne a pasję pszczelarską. Zmarł w Olsztynie w $1985 \mathrm{r}$.

Opracowując wspomnienia do druku, wydawcy skorzystali z maszynopisu ze zbiorów Archiwum PTL we Wrocławiu (sygn. 127/s), zgłoszonego na konkurs pamiętnikarski ogłoszony w początkach 1988 r. Widać z tego, że zgłoszenie wspomnień na konkurs nie było intencją autora, gdy pisał swój pamiętnik, nie liczył wówczas na jego publikację i dedykował go dzieciom, wnukom i prawnukom?.

Swoje wspomnienia Jan Konopielka podzielił na dwie części. Pierwsza z nich obejmuje lata 1906-1938, druga zaś - 1939-1956 ${ }^{10}$. W chronologicznie pierwszej

9 Ibidem, s. 154.

10 Ibidem, s. 17-56, 57-178. 
części autor dość szczegółowo opisał swoje wczesne dzieciństwo i młodość oraz pierwsze etapy kariery zawodowej w okresie międzywojennym. Pierwsze lata II wojny światowej zostały opisane z różnym poziomem szczegółowości, natomiast w centrum opisywanych wydarzeń autor wspomnień umieścił doświadczenie wieloletniego zesłania i tułaczki (1944-1956). Co ciekawe, wspomnienia wieńczy spotkanie z rodzeństwem mieszkającym na Sowieckiej Białorusi, nie zaś późniejsza repatriacja do Polski i połączenie się z żoną i dziećmi.

Opublikowane wspomnienia Konopielki z racji tego, że zawierają ogrom informacji dotyczących życia codziennego na zesłaniu, warunków pracy, relacji między więźniami a nadzorcami, a także współżycia samych uwięzionych, istotnie wzbogacają naszą wiedzę na ten temat. Autor dzieli się także swoimi obserwacjami życia społeczeństwa radzieckiego, którego częścią był przez wiele lat po wojnie. Przebywając najpierw w więzieniu, a potem w obozach GuŁagu, musiał odnaleźć się w ekstremalnie trudnych warunkach i samotnie, z dala od bliskich, walczyć o przeżycie. Z pewnością to jego niezłomny duch i ponadprzeciętne zdolności adaptacyjne, dzięki którym zyskał przed wojną awans społeczny, pozwoliły mu przetrwać lata zesłania.

Na zawartość wspomnień wpływa niewątpliwie to, że pisane one były w połowie lat 80. xx w., tuż przed śmiercią autora. Zdaniem redaktorów nie miały one szans na publikację i autocenzurę, ponieważ na konkurs pamiętników w 1988 r. materiał został wysłany przez rodzinę już zmarłego Konopielki ${ }^{11}$. Trudno się z tym zgodzić, skoro zawierały szczegóły trudne do zaakceptowania przez najbliższych. Z lektury pamiętnika wynika bowiem, że rodzina autora opuściła go w Związku Sowieckim, tuż po wojnie decydując się na repatriację, co nie mogło nie odcisnąć piętna na relacjach między autorem a jego żoną. Tymczasem wątki wydawałoby się ważne z punktu widzenia cierpiącej, samotnej jednostki są w pamiętniku pomijane, jakby na rzecz drobiazgowych opisów towarzyszy niedoli, oprawców i miejscowej ludności ${ }^{12}$.

W trzecim tomie serii (ale drugim zawierającym wspomnienia) opublikowano zapiski innego syna chłopskiego, Jana Wojdyły (1913-2003), pochodzącego z przedwojennej Małopolski Wschodniej ${ }^{13}$. W latach 1926-1933 pobierał on naukę w lwowskim III Gimnazjum Państwowym im. Stefana Batorego, a w latach 1935-1939 studiował na Wydziale Prawa Uniwersytetu Jana Kazimierza. W pierwszych dniach wojny ożenił się z Marią Olejarnik, absolwentką lwowskiego Seminarium Nauczycielskiego Żeńskiego im. Zofii Strzałkowskiej. Od czasów szkoły średniej udzielał się w ruchu narodowodemokratycznym, a w działalność stricte polityczną zaangażował

11 Ibidem, s. 8-9.

12 Ibidem, s. 154, 173-174.

13 J. Wojdyła, op. cit. 
się, wstępując do Stronnictwa Narodowego i podejmując na jego rzecz działalność organizacyjną oraz oświatowo-propagandową. Prowadził ją na terenie województw lwowskiego i wołyńskiego, zwłaszcza w środowisku wiejskim, jako referent gospodarczy Akademickiego Koła TSL. Współpracował też z organem prasowym lwowskiej endecji - „Słowem Narodowym”.

We wrześniu 1939 r. Wojdyła nie został zmobilizowany, a na przełomie 1939 i 1940 r. podjął działalność konspiracyjną na terenie Lwowa. Uczestniczył w przygotowaniu biuletynu zawierającego wiadomości pochodzące z nasłuchu stacji radiowych. W kwietniu 1940 r. zdecydował się na nielegalne przejście na Węgry. Wyprawa - dokładnie opisana w opublikowanych wspomnieniach - zakończyła się niepowodzeniem. Dobrowolnie wyjechał na teren Sowieckiej Ukrainy (1940-1941), a na początku września 1941 r. powrócił do Winnik (obecnie dzielnica Lwowa). Od 1941 r. zaangażował się tam w działalność konspiracyjną Narodowej Organizacji Wojskowej, rok później zaprzysiężony w AK (pseudonim „Maryniak”, później „Górniak”.). Pełnił funkcję inspektora terenowego Komendy Okręgu Małopolska Wschodnia Now. Od sierpnia 1943 r. objął kierownictwo Wydziału Propagandy okręgu, a 1 sierpnia 1944 r. stanął na czele Wydziału, walcząc zdecydowanie z sowieckim okupantem. W tym czasie groził mu pobór do armii sowieckiej, ale nie dostał powołania, symulując głuchotę. Został aresztowany na ulicy Lwowa 11 kwietnia 1945 r., gdy oczekiwał na spotkanie konspiracyjne. Po kilkumiesięcznym pobycie w obozie przejściowym na terenie miasta, w listopadzie 1945 r. został skazany na dziesięć lat pobytu w poprawczym obozie pracy i trafił do tzw. „Szirokłagu” w obwodzie mołotowskim (dziś permskim). Jako więzień pracował przy budowie tamy na rzece Koświe. Po trzech latach został zwolniony z możliwością repatriacji. Osiadł wraz rodziną w Prudniku (obecnie w województwie opolskim), z którym związał swoją karierę zawodową. Od grudnia 1948 r. pracował w miejscowym urzędzie skarbowym, następnie, do połowy lat 80. xx w., w Powiatowej Radzie Narodowej i Zarządzie Gospodarki Terenami (Wydziale Geodezji i Gospodarki Gruntami) Urzędu Miasta i Gminy w Prudniku.

Jeszcze pod koniec lat 50. xx w. Wojdyła, jako działacz katolicki, znajdował się w zasięgu zainteresowania komunistycznych służb bezpieczeństwa. Od lat 70. xx w. był mocno zaangażowany w życie społeczności kombatantów lwowskiej Now-AK, z biegiem lat stając się, w pewnym sensie, strażnikiem jej pamięci. Prowadził prace dokumentacyjne, a także wspierał inicjatywy wydawnicze, mające na celu odtworzenie konspiracyjnych dziejów tej grupy, pisał też teksty ku pamięci zmarłych koleżanek i kolegów, wspierał swoją wiedzą historyków podejmujących ten temat, spisał własne wspomnienia. Zmarł 2 czerwca $2003 \mathrm{r}$.

Podstawą omawianej edycji źródłowej pod redakcją Piotra Cichorackiego są dwa maszynopisy autorstwa Wojdyły, przechowywane w AN ZG PTL (sygn. 84/s [Ukrytem się w Związku Radzieckim], II egzemplarz - sygn. 880/s, oraz 317/s [Zaprietnaja zona - zakazana strefa]), liczące odpowiednio 122 i 180 stron. Część I powstała 
w 1988 r. w odpowiedzi na konkurs ogłoszony przez PTL, druga zaś, dotycząca pobytu w zSRR w latach 1945-1948, została nadesłana do zG PTL we wrześniu 1989 r. Istotą wyjątkowości wspomnień Jana Wojdyły zarówno na tle opublikowanych w tej serii, jak i pozostałych wspomnień znajdujących się w kolekcji AN PTL we Wrocławiu, jest status społeczny autora, jego wykształcenie i zaangażowanie polityczne.

Wspomnienia Wojdyły składają się z dwóch części, obejmujących zasadniczo okresy: 1940-1941 oraz 1945-1948 (ta w niewielkim zakresie obejmuje też czas późniejszy) ${ }^{14}$. W pierwszej części ważnym wątkiem jest szczegółowa relacja z nieudanej wyprawy na Węgry, podczas której - co niezbyt w tej sytuacji powszechne - udało mu się nie wpaść w ręce NKWD ${ }^{15}$, oraz opis ponad rocznego pobytu „na wolnej stopie” w Krzywym Rogu i jego okolicach. Jest to zapewne jedno z nielicznych świadectw pobytu Polaka na Ukrainie radzieckiej w charakterze dobrowolnego robotnika. Wojdyła czyni przy tym ciekawe obserwacje natury społecznej, dotyczące zarówno interakcji w polsko-ukraińsko-żydowskiej społeczności przyjezdnych robotników, jak i ich stosunków z lokalną ludnością. Autor nie ukrywa, że dobrowolni robotnicy zatrudnieni w branży, do której został przydzielony, mogli cieszyć się namiastką przywilejów socjalnych, takich jak możliwość zaopatrzenia w towary niedostępne dla innych obywateli radzieckich, czy nawet urlopy. Wyjątkowe są także jego impresje o życiu codziennym w zsRR u progu wojny niemiecko-radzieckiej. Przedsięwzięty na własną rękę i w dużej mierze pieszy powrót do Winnik wpłynął na jego własny obraz Radzieckiej Ukrainy. Dla mnie w tych wspomnieniach najcenniejsze są uwagi autora na temat Polaków, którzy pozostali po sowieckiej stronie granicy ryskiej z 1921 r., a z którymi Wojdyła zetknął się w okolicach Płoskirowa ${ }^{16}$. Warto też zwrócić uwagę na warstwę stylistyczną wspomnień - opisując swoją wyprawę przez Podole, autor czyni liczne odniesienia do powieści Henryka Sienkiewicza Ogniem i mieczem.

W drugiej części swojego pamiętnika Wojdyła najwięcej uwagi poświęca represjom radzieckim, jakich doświadczył od momentu aresztowania w kwietniu 1945 r. Ta część opublikowanych wspomnień wpisuje się więc w nurt literatury poświęconej losom Polaków na Wschodzie w latach II wojny światowej. W warstwie informacyjnej część ta wykracza poza cezurę lat 1945-1948. Znajdziemy tu przyczynki do historii lwowskiej konspiracji narodowej od wkroczenia do miasta Armii Czerwonej w lipcu 1944 r. (m.in. nazwiska uczestników i daty wydarzeń istotnych dla Wojdyły). Znalazły się tu również wrażenia autora po powrocie z zesłania i opis procesów adaptacyjnych powojennego społeczeństwa polskiego,

Por.: ibidem, s. 15-70, 171-330.

Ibidem, s. 30-41.

Ibidem, s. 151-159. 
w tym wzmianki o powojennych dziejach Prudnika i całej Opolszczyzny, w raz z pozostałą tam ludnością autochtoniczną, której los nie był autorowi obojętny.

Warto odnotować, że Wojdyła na kartach swego pamiętnika stworzył bardzo rzeczowy opis: nie ukrywa tego, że niekiedy przywołuje opinie zasłyszane, których nie był w stanie zweryfikować, jego oceny sytuacji, w tym opinie na temat radzieckiego aparatu represji, są wyważone, a własne doświadczenia przedstawia bez tonu martyrologicznego. Podobnie jak w części I, interesująco odtwarza relacje z współtowarzyszami niedoli innych narodowości. Obszerny fragment poświęca też kilkutygodniowej podróży z łagru do Polski. Zdaniem redaktora opracowania w obu częściach Wojdyła pozostaje natomiast krytyczny wobec samego siebie, co szczególnie mocno wybrzmiewa w kilku fragmentach dotyczących życia osobistego, zwłaszcza relacji z najbliższymi ${ }^{17}$. W mojej opinii jednak wyznanie pamiętnikarza o tym, że stał się dla żony źródłem cierpienia i rozczarowań, nie jest przejawem dystansu wobec siebie, lecz goryczy, dostrzegalnej jeszcze w wielu innych miejscach wspomnień Wojdyły ${ }^{18}$.

Kolejny tom wspomnień w recenzowanej serii, tym razem pod redakcją M. Ruchniewicz, jest jedynym jak dotąd opublikowanym tu pamiętnikiem autorstwa kobiety ${ }^{19}$. Jego autorka, Ewa Antonina Sobota-Grün (1921-2011) urodziła się w Stryju w rodzinie inteligenckiej. Wczesne lata dzieciństwa spędziła wraz z dwójką rodzeństwa na Białostocczyźnie, a w 1935 r. rozpoczęła naukę w szkole średniej - Gimnazjum i Liceum im. Tadeusza Kościuszki w Bielsku Podlaskim. Po wybuchu II wojny światowej ojciec autorki zdecydował się nielegalnie przekroczyć granicę między strefami okupacyjnymi i osiadł w Jaśle, a w tym czasie Ewa wraz matką i rodzeństwem została deportowana do Ałtajskiego Kraju w Rosyjskiej FSRR, gdzie spędziła pięć lat zesłania, pracując najpierw w sowchozie „Proletarka”, a od lutego 1942 r. podejmując różne zajęcia w osiedlu rejonowym Ałtajskoje. Tam powstała mała polska społeczność, próbująca przeżyć - podobnie jak miejscowa ludność i kolejne grupy zesłanych i ewakuowanych - w coraz cięższych warunkach wojennych.

Za odmowę przyjęcia obywatelstwa radzieckiego w 1943 r. Ewa Sobota wraz matką i bratem trafiła do więzienia. W tym samym roku brat autorki, Krzysztof, został zmobilizowany do 1 Armii Polskiej, organizacyjnie podporządkowanej Naczelnemu Dowództwu wr, a operacyjnie - dowódcom frontów Armii Czerwonej. W 1944 r. Ałtajskoje zostało objęte działalnością Związku Patriotów Polskich, a autorka wspomnień została jednym z dwóch przedstawicieli miejscowej społeczności polskich zesłańców, współpracujących z oddziałem organizacji 
w Bijsku: uczestniczyła w rozdzielaniu zapomóg i tworzeniu spisów przebywających w miejscowości Polaków. Do kraju wróciła transportem repatriacyjnym wraz z matką i siostrą w 1946 r., po prawie półrocznej podróży. W kraju udało jej się też połączyć z ojcem i bratem. Po wojnie ukończyła Liceum Pedagogiczne Gorlicach i Studium Nauczycielskie i została nauczycielką języka rosyjskiego. Zamieszkała w Jaśle wraz z mężem Stanisława Grünem i dziećmi. Na emeryturę przeszła w 1980 r., jednak doświadczenie zesłania determinowało dalszy kierunek jej działalności społecznej: na przełomie lat 80. i 90. xx w. pełniła funkcję sekretarza w miejscowym kole Związku Sybiraków.

Podstawą omawianej edycji jest maszynopis zgłoszony w 1989 r. na wspomniany konkurs pamiętnikarski, przechowywany w AN PTL pod sygn. 314/s. i liczący 177 stron. Wykorzystano także odręczne notatki, które autorka sporządzała na zesłaniu (niewielki zeszyt, w którym na ok. 30 stronach Ewa Sobota w lutym 1942 r. opisywała początek deportacji i notowała miejscowości na trasie przejazdu pociągu) ${ }^{20}$. Partie tekstu w maszynopisie, powiązane z wcześniej powstałymi notatkami, opatrzone zostały przez nią, choć nie w sposób konsekwentny, datami dziennymi. Zapisy w zeszycie nie są jednak tożsame z tekstem w maszynopisie, który stał się podstawą tej edycji - redaktorzy tomu dostrzegli rozbieżności i zdecydowali się na udostępnienie czytelnikom także tych przeredagowanych fragmentów wspomnień, dodając w przypisach treść fragmentów rękopiśmiennych, które uzupełniają przekaz o wewnętrzne, spisywane na gorąco przeżycia zesłanej.

Zdaniem autorki opracowania wspomnienia Ewy Soboty-Grün określić można jako klasyczny niemal przykład literatury zesłańczej, powstającej w dużej ilości i chętnie publikowanej na przełomie lat 80. i 90. xx w. Tekst zatytułowany Podróż w nieznane 1939-1946 i podpisany pseudonimem Syberiuszka ${ }^{21}$ nie jest pisany w konwencji martyrologicznej: autorka dostrzega wokół siebie innych cierpiących, kolejne grupy represjonowanych czy miejscowych obywateli radzieckich, z którymi - z racji miejsca zamieszkania czy pracy - ma codzienny kontakt, a analizując po latach obrazy utrwalone w pamięci, zachowuje często krytyczne do nich podejście. Sobota-Grün przedstawia szczerze różne postawy prezentowane w jej otoczeniu w tym ekstremalnym czasie walki o przeżycie, a czytelnik może czasem wyczuć pewien zawód czy rozgoryczenie autorki z powodu zachowania współtowarzyszy zesłania. Ciekawe są tu zwłaszcza fragmenty wspomnianego pamiętnika z czasów wojny, umieszczone przez redaktorkę w przypisach dolnych, które zresztą korzystnie wyróżniają omawiane wydanie na tle innych tomów w serii czy w ogóle w „Bibliotece Zesłańca”. 
W opublikowanym pamiętniku Ewy Soboty-Grün najwięcej informacji dotyczy okresu do 1943 r., który w maszynopisie zajmuje około trzy czwarte treści. Autorka relacjonując szczegółowo pierwsze miesiące życia i pracy w obcym i egzotycznym otoczeniu, odtwarza proces stopniowego poznawania miejscowych warunków i reakcję polskiej społeczności na nową sytuację. Zdobywanie środków do życia dla rodziny należało do niej samej i jej młodszego brata: pracowali przy sianokosach na górskich połoninach sowchozu, przy budowie elektrowni i w różnych zakładach pracy. Kulminacją narracji jest zdławiona przez władze w pierwszych miesiącach 1943 r. próba oporu części Polaków, w tym rodziny autorki, wobec ponownego zmuszania ich do przyjęcia obywatelstwa radzieckiego oraz powołanie brata do szeregów polskich oddziałów wojskowych tworzonych w Sielcach nad Oką. Kolejne ponad dwa lata zesłańczej egzystencji autorka opisała już dość pobieżnie. Niezmiennie trudne warunki życia, bieda i odwlekająca się perspektywa repatriacji sprawiły, że czas ten złożony był z podobnych do siebie, wypełnionych powtarzalnymi czynnościami tygodni i miesięcy. Finałem wspomnień jest relacja z wyczerpującej podróż w transporcie repatriacyjnym, a spotkanie z ojcem w Łężynach (ok. $13 \mathrm{~km}$ od Jasła) wieńczy narrację. Jako dygresję traktować trzeba umieszczony na końcowych stronach opis żołnierskich losów brata autorki, w tym jego dezercji w $1945 \mathrm{r}$.

Zmysł obserwatorski i talent literacki pozwoliły pamiętnikarce snuć opowieść o zesłaniu, w którą wplatała różne historie z codziennego życia i spostrzeżenia na temat relacji międzyludzkich. Na kartach pamiętnika Sobota-Grün jawi się jako osoba otwarta i ciekawa świata. Niezwykle cenne są, w mojej opinii, etnograficzne opisy, jakich dostarcza czytelnikowi na temat powszechnie panującej biedy, ale też zwyczajów i tradycji kulinarnych lokalnych społeczności²2. Istotny dla omawianych wspomnień jest także wiek autorki w chwili zesłania - o wydarzeniach, które stały się udziałem jej rodziny, opowiada ona bowiem z perspektywy młodej, ale już wchodzącej w dorosłość uczennicy, a zatem to, co w dużej mierze pamięta sama.

Autorem ostatniego tomu wspomnień, który ukazał się w recenzowanej serii, jest Henryk Andrzej Łęczycki (1903-1979) ${ }^{23}$, urodzony w Warszawie jako najmłodszy z czworga dzieci w rodzinie Stanisławy Sikorskiej i Witolda Łęczyckiego. Dzieciństwo i młodość spędził w Warszawie, gdzie zdobył wykształcenie. W 1920 r. służył ochotniczo w Wojsku Polskim podczas wojny polsko-bolszewickiej. W 1927 r. w Piotrkowie Trybunalskim poślubił studentkę historii Uniwersytetu Warszawskiego Marię Michalską. Był absolwentem Wydziału Inżynierii Lądowej Politechniki Warszawskiej. Po uzyskaniu dyplomu dostał propozycję 
pracy w Trembowli (wówczas powiatowe miasto w woj. tarnopolskim), gdzie do wybuchu II wojny światowej pracował jako kierownik Powiatowego Zarządu Drogowego. Wraz z żoną Marią wychowywał trójkę dzieci: Andrzeja (ur. 1929 r.), Witolda (ur. 1933 r.) i Agnieszkę (ur. 1938 r.).

Po wkroczeniu Armii Czerwonej do Trembowli Łęczycki został aresztowany przez NKWD, a po półtoramiesięcznym śledztwie przewieziony do więzienia w Tarnopolu. Wszyscy jego najbliżsi i rodzina żony 13 kwietnia 1940 r. zostali wywiezieni do Kazachstanu, a samego Łęczyckiego umieszczono w więzieniu w Kirowogradzie, gdzie Kolegium Specjalne przy nKwD skazało go na osiem lat poprawczego obozu pracy. Stamtąd w maju 1941 r. został przetransportowany do obozu pracy w Bezimience w okolicach Kujbyszewa (obecnie Samara). Ponadroczny pobyt w więzieniu oraz praca w obozie znacznie nadwerężyły jego zdrowie. Po zawarciu w lipcu 1941 r. układu Sikorski-Majski i ogłoszeniu amnestii dla obywateli polskich znajdujących się na terenie zSRR, Henryk Łęczycki postanowił za wszelką cenę odnaleźć rodzinę. Posiadając zaledwie kilka niepewnych wzmianek o jej losach, szczęśliwie odnalazł swych bliskich w wiosce Bolszaja Bukoń w obwodzie wschodniokazachstańskim, a po kilku miesiącach rekonwalescencji znalazł pracę jako inżynier drogowy w Kokpekty.

W lutym 1942 r. autor wstąpił do polskiej armii pod dowództwem gen. Władysława Andersa, przydzielony do batalionu saperów 10 Dywizji Piechoty Polskich Sił Zbrojnych w zSRR, a 17 marca 1942 r. wraz z częścią armii został ewakuowany do Iranu. Wraz z jednostką trafił kolejno do Iraku, Palestyny i Egiptu, a potem został przeniesiony do dowództwa saperów 3 Dywizji Strzelców Karpackich. Na przełomie 1943 i 1944 r. wraz z 2 Korpusem został przetransportowany do Włoch i w maju 1944 r. walczył na linii Gustawa w 3 Dywizji Strzelców Karpackich, w 3 Baonie Saperów, brał też udział w bitwie pod Monte Cassino. W czerwcu 1945 r. odkomenderowany do 20 Baonu Saperów, następnie przetransportowany do włoskiego Fano, i dalej - w ramach 2 Korpusu - do Wielkiej Brytanii, gdzie podjął decyzję o powrocie do kraju. Łęczycki oczekiwał na podróż do Polski w obozie repatriacyjnym na terenie Szkocji, skąd przez Edynburg wypłynął do portu w Gdyni. Ze swoją rodziną, która została repatriowana z ZSRR w 1946 r., spotkał się w kwietniu 1947 r. we Wrocławiu.

Po wojnie Łęczycki pracował początkowo w Wojewódzkiej Komisji Planowania Gospodarczego we Wrocławiu, następnie w Wydziale Komunikacji tamtejszego Urzędu Wojewódzkiego. W latach 1950-1953 pełnił funkcję kierownika Działu Inwestycji w Wojewódzkim Zarządzie Dróg Publicznych, a najdłużej związany był z Politechniką Wrocławską, gdzie w latach 1954-1960 pełnił m.in. funkcje prodziekanów. Angażował się także w działania społeczne, m.in. przez kilka kadencji był członkiem i zastępcą przewodniczącego Komisji Żeglugi, Komunikacji i Łączności przy Prezydium Wojewódzkiej Rady Narodowej we Wrocławiu. Za swoją pracę zawodową i społeczną został uhonorowany Krzyżem Kawalerskim 
Orderu Odrodzenia Polski, Medalem xxv-lecia Dolnego Śląska i Złotą Odznaką „Zasłużony dla Dolnego Śląska”. Mimo licznych aktywności obywatelskich i pełnionych funkcji zawodowych, nigdy nie wstąpił do PZPR.

Podstawą edycji wspomnień Łęczyckiego jest liczący 151 stron maszynopis o sygnaturze 706/s, przechowywany w AN zG PTL we Wrocławiu, wysłany przez synów autora, Andrzeja i Witolda Łęczyckich, na konkurs pamiętnikarski PTL ogłoszony w styczniu 1988 r. Maszynopis został sporządzony przez potomków autora na podstawie rękopisu powstałego w latach 70. $\mathrm{xx}$ w., a opublikowane wspomnienia obejmują okres okupacji sowieckiej oraz szlak bojowy Henryka Łęczyckiego. Sam autor podzielił swoje zapiski na 10 zatytułowanych rozdziałów. Wspomnienia rozpoczyna wątek dotyczący wybuchu II wojny światowej, a kończy moment połączenia się z rodziną w 1947 r. Znajdują się w nich również odniesienia do wcześniejszych doświadczeń i przeżyć autora (np. krótki fragment dotyczący bitwy warszawskiej 1920 r., w której autor brał udział jako ochotnik), pobieżnie tylko opisany został okres półrocznego ratowania zdrowia we wsi Bolszaja Bukoń i pracy jako inżynier drogowy w rejonie kokpektyńskim.

Na tle licznych publikacji dokumentujących szlak bojowy Armii gen. Andersa pamiętnik ten wyróżnia to, że jego autor w czasie opisywanych wydarzeń był osobą dojrzałą, mającą już doświadczenie życiowe i zawodowe. Pierwsze dni wojny w Trembowli opisuje z perspektywy pracownika administracji, w interesujący sposób ukazując niepewność i rozprzężenie narastające we władzach miasta od chwili wybuchu wojny, oraz pogrążanie się miasta w chaosie ${ }^{24}$. Nie unika też opisu doświadczonych represji politycznych: dokładnie opisuje okoliczności aresztowania i miesiące spędzone w więzieniu w Tarnopolu, charakteryzuje osoby poznane w areszcie, przytacza przebieg przesłuchań, nastroje panujące w celach, a także choroby trapiące więźniów, np. powszechny świerzb. Opisując pobyt w więzieniach oraz pracę w obozie w Bezimience, stara się rzeczowo zrelacjonować zarówno warunki w miejscu odosobnienia, plan dnia, jak i panujące wśród aresztantów nastroje; przytacza też informacje geograficzne i historyczne oraz iście reporterskie spostrzeżenia o odmienności kulturowej napotkanych podczas swojego zesłania grup czy też zachowania ludzkie w sytuacji ekstremalnej, przytaczając własne sposoby radzenia sobie w nowych warunkach ${ }^{25}$. Autorka opracowania i wstępu, Marcelina Jakimowicz, podkreśla, że pamiętnik Henryka Łęczyckiego z encyklopedyczną dokładnością i pietyzmem tłumaczy czytelnikowi codzienność zesłańca-łagiernika, o czym świadczą wykonane przez autora

24 Chodzi o opis ewakuacji Banku Polskiego oraz zrelacjonowanie nastrojów panujących wśród reprezentantów władz miejskich. Zob.: ibidem, s. 23-29.

25 Przykładem jest np. fragment odnoszący się do zdobywania narzędzi i materiałów potrzebnych do reperowania zniszczonej odzieży w czasie pobytu w areszcie. Zob.: ibidem, s. $41-50$. 
pamiętnika przypisy wyjaśniające niektóre treści w pamiętniku ${ }^{26}$. Istotne jest dla niego złożenie świadectwa o terrorze komunistycznym, którego padł ofiarą, stąd szczególnie ważny wydaje się opis wędrówki do miejsca deportacji rodziny Łęczyckiego i chwila odnalezienia najbliższych - widać w nim dylemat człowieka doświadczonego i niepewnego przyszłości, który za wszelką cenę pragnie odszukać bliskich, by nie zatracić też i samego siebie.

Jednakże autor unika emocji. Jego wspomnienia odnoszące się do działań na froncie cechuje prostota opisu; autor przedstawia wybrane epizody, unikając zbytniego patosu. Stara się w reporterski sposób ukazać najważniejsze swoje spostrzeżenia i wydarzenia. Niekiedy myli się w datach, imionach dowódców, ale przecież wiemy, że pamięć ludzka bywa zawodna.

Pamiętnik Łęczyckiego, podobnie jak pamiętnik Wojdyły, nie był pomyślany jako praca konkursowa, lecz stanowił samodzielne dzieło adresowane do najbliższych. Oryginał zawierał już aparat naukowy, sporządzony przez autora, który został zachowany i wyeksponowany w publikacji. Wartościowym zabiegiem redaktorskim było też przywołanie we wstępie wspomnień żony autora, Marii Łęczyckiej, wydanych w formie zbeletryzowanej. Marcelina Jakimowicz zręcznie zestawia tu ze sobą wyzute z emocji opisy scen z życia na zesłaniu i powojennego spotkania z rodziną $\mathrm{w}$ wersji Łęczyckiego z pełnymi afektu opisami tych samych zdarzeń w pamiętniku jego żony ${ }^{27}$. Dzięki tym zabiegom edycja jest niezwykle cenna dla badaczy tematyki, ponieważ pozwala na zbadanie takich aspektów opisanych w pamiętnikach wydarzeń, które wykraczają poza poszukiwanie faktów historycznych w źródle osobistym.

Podsumowując, chciałabym zwrócić uwagę, że omawiane tu cztery tomy wspomnień z nowej podserii wydawniczej w ramach „Biblioteki Zesłańca”, mają ze sobą wiele wspólnego, zwłaszcza jeśli chodzi o dokumentowanie zesłania i tułaczki z czasów wojny. Z lektury wszystkich omawianych wspomnień wyłania się obraz walki o przetrwanie na przekór niemocy wobec terroru władzy, pomimo poczucia beznadziei. Wybrane do publikacji wspomnienia łączą wątki dotyczące osobistych bolesnych przeżyć z refleksjami na temat otaczającej rzeczywistości. Wiele jest w nich również informacji o kontaktach z zesłańcami, więźniami innych narodowości lub z rdzenną ludnością Syberii i Kazachstanu. Wspomnienia stanowią doskonałe źródło do badania tragizmu codziennej egzystencji zesłańców i jawią się niczym inna odsłona tej samej powieści o Sybiriadzie polskiej w xx w. Każda z tych historii przetrwania jest inna (tak wiele o tym decyduje) i każda na swój sposób 
jest wyjątkowa, o czym redaktorzy każdego z tomów przekonują nadto w odnośnych wstępach ${ }^{28}$.

O wyjątkowości źródeł osobistych decyduje ich subiektywizm, dlatego mogą one także zawierać błędy faktograficzne, pomyłki czy przeoczenia, zwłaszcza że powstały wiele lat po opisywanych wydarzeniach. Zdarza się też tak, że na etapie pracy redakcyjnej nie wszystkie te błędy da się poprawić. We wszystkich tomach zamieszczono przypisy rzeczowe, zawierające wyjaśnienia dotyczące miejsc pobytu autorów, osób, o których udało się znaleźć informacje, oraz objaśnienia faktów lub pojęć, które dla współczesnego czytelnika mogłyby być niezrozumiałe. W wypadku braku informacji redaktorzy zrezygnowali z tworzenia odwołania. W przypisach redaktorskich zawarto także wyjaśnienia zarówno nielicznych pomyłek, jak i skrótów myślowych autorów wspomnień. We wstępie do każdego z omawianych tomów redaktorzy każdorazowo przedstawiają założenia edytorskie, przyjęte w nowej serii. W ten sposób czytelnik dowiaduje się na początku, że we wszystkich czterech tomach redaktorzy nawiązują do tradycji „Biblioteki Zesłańca” i ingerują redakcyjnie w tekst jedynie z konieczności, korygując interpunkcję i uwspółcześniając ortografię. Poprawki gramatyczne i stylistyczne dostrzec można jedynie w przypadkach, gdy wersja autorska istotnie utrudniałaby zrozumienie tekstu. Redaktorzy dokonują nieraz drobnych uzupełnień (brakujące wyrazy), które oznaczono nawiasami kwadratowymi. Pozostawiono jednak bez zmian fonetycznych zapisy wypowiedzi w językach obcych; każdorazowo w objaśnieniach podano tłumaczenie na język polski. Redaktorzy starali się ponadto opatrzyć przypisami każdą występującą w tekście postać, ważniejszy epizod historyczny, utwór literacki itp. W przypisach dotyczących nazw miejscowości znajdujących się na terytorium II Rzeczypospolitej odwoływano się do struktury administracyjno-terytorialnej z okresu międzywojennego. Nie opatrywano przypisami miast mających w okresie międzywojennym status powiatu i wyższy. W wypadku kilku miejscowości poza terytorium II RP nie udało się ich zidentyfikować, być może w wyniku błędnego zapisu poczynionego przez autorów. W razie odwołania się przez autora do publikacji zwartych w przypisach umieszczano informację o pierwszym polskim wydaniu danego dzieła. W ten sposób wszystkie komentarze zawarte w każdym z omawianych tekstów wspomnień stanowią istotny dodatek, jednak nie są tekstem równoległym; są uzupełnieniem, a nie wyjaśnieniem błędów autora wspomnieńn ${ }^{29}$.

Upatruję w tym duży szacunek dla autorów wspomnień i do ich doświadczenia. Jest w tym też przestrzeń na interpretację badaczy, którzy sięgną po omawia-

28 Por.: J. Konopielko, op. cit., s. 8-12; J. Wojdyła, op. cit., s. 9-12; E. Sobota-Grün, op. cit., s. 10-11; H. Łęczycki, op. cit., s. 12-13.

29 Por.: J. Konopielko, op. cit., s. 13-14; J. Wojdyła, op. cit., s. 13; E. Sobota-Grün, op. cit., s. 12; H. Łęczycki, op. cit., s. 14 . 
ne tomy w swojej pracy naukowej. Jednakże w wydawnictwie źródłowym bardzo ważnym aspektem jest warsztat edytorski redaktorów serii, dlatego nie we wszystkich przypadkach można sobie pozwolić na pozostawienie oryginału bez komentarza. Na końcu każdego tomu umieszczono wprawdzie bibliografię, z której redaktorzy korzystali, przygotowując każdorazowo edycje do druku ${ }^{30}$, moją uwagę przykuł jednak brak w każdej z nich źródeł o charakterze słownikowym i encyklopedycznym, objaśniających realia obozów sowieckich, tak wiele miejsca zajmujące w opublikowanych pamiętnikach. Rzecz w tym, że autorzy pisząc swoje wspomnienia, wielokrotnie posługują się pojęciami, których znaczenie wyraźnie wykracza poza definicje słownika języka rosyjskiego. Językowy obraz świata polskich zesłańców został bowiem istotnie poszerzony o rosyjską gwarę więzienną, wytworzoną na potrzeby konieczności opisu otaczającej ich rzeczywistości GuŁagu. Mam tu na myśli np. słowniki opracowane przez Jacques’a Rossiego ${ }^{31}$ i Leonida Gorodina ${ }^{32}$ - byłych więźniów GuŁagu, którzy w swoich opracowaniach odnieśli osobiste doświadczenie do wiedzy akademickiej, dając badaczom tej tematyki usystematyzowaną wiedzę na temat tego, jak doświadczanie zniewolenia znalazło swoje odbicie w języku rosyjskim i jak należy właściwie interpretować tę nowomowę więzienną pojawiającą się we wspomnieniach i w pamiętnikach osób doświadczonych przez sowiecki aparat represji w xx w. Słowniki te dają autorom edycji takich wspomnień dobry punkt odniesienia do definiowania i wyjaśniania realiów obozowych współczesnemu czytelnikowi.

W opublikowanych tekstach zdarzają się odmienne tłumaczenia tego samego pojęcia. I tak u Konopielki słowo dohodiaga przetłumaczono w przypisie dolnym 191 jako więźnia skrajnie wyczerpanego, a kilka stron dalej, w przypisie 221 - jako więźnia w ostrym stadium wyczerpania organizmu ${ }^{33}$. Natomiast u Wojdyły dość ważne z punktu widzenia opisu życia obozowego, pojęcie pridurok/i raz wyjaśniono jako osobę uprzywilejowaną, a innym razem -jako więźnia funkcyjnego ${ }^{34}$. Zgodnie z definicjami Gorodina i Rossiego określano tak więźnia niepracującego fizycznie, co było zarówno przywilejem (na tle

30 J. Konopielko, op. cit., s. 207-208; J. Wojdyła, op. cit., s. 345-347; E. Sobota-Grün, op. cit., s. 197-198; H. Łęczycki, op. cit., s. 187-189.

31 Ж. Росси, Справочникпо ГУЛАГу, в 2m., изд. 2-е, доп., Москва 1991. Jacques Rossi to pseudonim Franciszka K. Heymana ur. we Wrocławiu (1909-2004), francusko-polskiego językoznawcy, poligloty, pisarza tematyki łagrowej, leksykografa mowy GuŁagu.

32 Л. Городин, Словарь русских арготизмов. Лексикон каторги и лагерей императорской и советской России, Москва 2021. Leonid Gorodin (1907-1994) był radzieckim publicystą ukraińskiego pochodzenia, trzykrotnym więźniem GuŁagu do poł. lat 50. xx w., który w wolnym od obowiązków zawodowych czasie od poł. lat 6o. xx w. potajemnie opracowywał słownik nowomowy więziennej, wydany po jego śmierci dzięki staraniom syna. Por.: J. Konopielko, op. cit., s. 114, 124. Por.: J. Wojdyła, op. cit., s. 238, 256. 
innych pracujących fizycznie współwięźniów), jak i wiązało się z wykonywaniem innego rodzaju pracy (funkcji) ${ }^{35}$.

Niektóre pojęcia pozostały w edycjach w ogóle bez redaktorskiego wyjaśnienia, pomimo ich wyróżnienia w tekście głównym. U Konopielki takim powtarzającym się słowem jest stacjonar ${ }^{36}$, we wspomnieniach Wojdyły - wierbowszczyk ${ }^{37}$, kapezet $^{38}$, trofej $^{39}$ i zarietnaja zona ${ }^{40}$, zaś u Soboty-Grün trzykrotnie pojawia się określenie wyhodnoj den'/wychodnojden', przy czym w realiach opisanych przez pamiętnikarkę chodzi o to, że tydzień pracy liczył $6 \mathrm{dni}$, co wymaga dodatkowego wyjaśnienia w przypisie dolnym ${ }^{41}$. Tu nadto nie zostają wyjaśnione takie pojęcia, jak telezhka ${ }^{42}, k i z i a k i^{43}$ i specposelency ${ }^{44}$, których wyjaśnienie może być zbędne dla znawców tematyki, ale czyni to opracowanie bardziej hermetycznym. Tracą na tym bogate opisy realiów życia miejscowej ludności, np. Ewa Sobota-Grün wspomina o herbacie cegiełkowej (kirpichyj chaj), co w przypisie zostaje wyjaśnione jedynie poprzez tłumaczenie ${ }^{45}$. Tymczasem w tej części świata z przyrządzaniem tego rodzaju herbaty, dodajmy - najniższego gatunku, wiązały się określone rytuały kulinarne, a także była ona używana przez ludność rdzenną jako środek płatniczy $\mathrm{w}$ handlu wymiennym ${ }^{46}$. Podobnie jest $\mathrm{z}$ brakiem wyjaśnienia słów lawoczka (właśc. Ławoczka) ${ }^{47}$ i stolypinka (właśc. stołypinka) ${ }^{48} \mathrm{w}$ opracowaniu wspomnień Henryka Łęczyckiego, przy czym dość szczegółowo wyjaśniono nazwy oper Verdiego i to, kim był Franciszek Liszt ${ }^{49}$.

Część wyjaśnień w przypisach dolnych nie wyczerpuje też całego spektrum znaczeniowego słowa użytego przez pamiętnikarza. Jako przykład chciałam

Por.: Ж. Росси, op. cit., s. 307; Л. Городин, op. cit., s. 194.

J. Konopielko, op. cit., s. 124-125.

J. Wojdyła, op. cit., s. 46.

Ibidem, s. 199.

Ibidem, s. 217.

Ibidem, s. 226.

Por.: E. Sobota-Grün, op. cit., s. 97, 99, 102.

Ibidem, s. 117.

Ibidem, s. 141.

Ibidem, s. 114 .

Ibidem, s. 167.

Р.А. Бекназаров, Казахи и чай: историко-этнографическое исследование, „Этнографическое обозрение”, Nr 5 (2009), s. 51-62.

H. Łęczycki, op. cit., s. 53.

Ibidem, s. 59.

Ibidem, s. 144-145. 
przy toczyć pojawiające się u Wojdyły pojęcia bojec ${ }^{50}$, balanda ${ }^{51} \mathrm{i}$ bronia ${ }^{52}$, które zostały przetłumaczone przez autora edycji sytuacyjnie, w oderwaniu od znaczenia słownikowego, jednakże bez stosownej adnotacji o tym, że przypis objaśnia jedynie określony aspekt znaczenia, a nie całe pole semantyczne tego słowa. Bojec nie jest bowiem pojęciem z języka potocznego - tak określano szeregowców w Robotniczo-Chłopskiej Czerwonej Armii Związku Sowieckiego; balanda to w gwarze więziennej określenie wodnistej zupy, bez wartości odżywczych ${ }^{53}$. Bronia zaś jest, co prawda, elementem ochronnym żołnierskiego umundurowania, jednakże pamiętnikarz ma na myśli bron', co w definicji słownikowej oznacza rezerwację, a w czasach wojny radziecko-niemieckiej (1941-1945) w odniesieniu do mężczyzn w wieku poborowym oznaczało odroczenie od wcielenia do regularnej armii. Ten rodzaj odroczenia od mobilizacji obejmował mężczyzn wykonujących określone zawody i/lub pełniących ważne funkcje społeczne (kierownictwo partii, dyrektorzy fabryk itp.).

Także w edycji wspomnień Ewy Soboty-Grün popełniono błąd w wyjaśnieniu znaczenia terminu brannaja recz' (materszczina). W przypisie wyjaśniającym autorka opracowania pisze o matnym jazyku, jednakże chodzi o maternyj jazyk albo maternuju recz'. Podana w wyjaśnieniu definicja słowa mat jest niezgodna z odpowiednią definicją etymologicznego słownika języka rosyjskiego, który wskazuje na pochodzenie tego słowa od słowiańskiego mat (głośno krzyczeć) ${ }^{54}$.

Odnotowałam także przypadki, w których autor tekstu używa poprawnej polszczyzny w opisie niektórych realiów sowieckich, tymczasem w przypisie dolnym ten fragment jest dodatkowo tłumaczony poprzez egzotyzację. W przypisie 334 w edycji wspomnień Konopielki pojawia się określenie wyzow definiowane sytuacyjnie jako zaproszenie pozwalające autorowi wyjechać ze Związku Sowieckiego. Tymczasem w tekście Konopielko nie użył tego określenia, lecz napisał o zaproszeniu od rodziny w PRL, na które czekał od lat ${ }^{55}$. Narrację Jana Wojdyły cechuje duża świadomość językowa, która pozwala mu odróżniać język rosyjski od języka ukraińskiego - zabrakło jej jednak edytorowi tekstu, o czym świadczy następujący przykład: gdy autor wspomina o silradach (ukr. spółdzielniach wiejskich)

50 J. Wojdyła, op. cit., s. 78.

51 Ibidem, s. 231.

52 Ibidem, s. 204-205.

53 Ж. Росси, ор. cit., s. 21.

54 История слов: ок.150о слов и выражений и более 5000 слов с ними связ., состав. В. В. Виноградов, Москва 1999. Dostępne na: https://azbyka.ru/otechnik/Spravochniki/ istorija-slov/5 (dostęp: 3 XII 2021 r.).

55 J. Konopielko, op. cit., s. 174. 
w tekście przypisu dolnego podano, że chodzi o sielsowiety (określenie tego samego w języku rosyjskim) $)^{56}$.

W tym miejscu chciałabym podkreślić, że żaden badacz tematyki sybirackiej nie będzie potrzebował wyjaśnień ani nowomowy obozowej, ani większości opisanych przez pamiętnikarzy, a pominiętych przez redaktorów serii w przypisach dolnych, realiów. Poszłabym dalej i powiedziała, że jeśli adresatami edycji są badacze wspomnianej tematyki, to przypisy nieautorskie w ogóle są zbędne. Jednakże nie jest to lektura mająca pogłębiać wiedzę osób będących na początku drogi, zwłaszcza jeśli zabraknie wyjaśnienia realiów opisywanych w pamiętniku. Jest to rzecz jasna kwestia dyskusyjna, jednak, analizując edycje źródeł, zawsze zadaję sobie pytanie o to, kto jest właściwie adresatem ogromu pracy redakcji wkładanej w przygotowanie edycji źródła.

Aby objaśnić skalę trudności jakie czytelnik nieprzygotowany do lektury omawianych pamiętników może mieć obecnie i w przyszłości, pozwolę sobie na dygresję odnośnie do tytułu mojego omówienia, w którym celowo nawiązuję do jednej z piosenek Anny German, polskiej piosenkarki estradowej pochodzenia niemieckiego, która karierę zrobiła także (albo przede wszystkim) w Związku Radzieckim. Gdybym pisała swoje omówienie pod koniec lat 80. xx w., wyjaśnienie tytułu oraz osoby piosenkarki byłoby zupełnie zbędne. Czytelnik bez większego trudu zrozumiałby moje nawiązanie, mógłby też polemizować z jego trafnością. Wszak Anna German przed 1939 r. nie była obywatelką II RP, nie była nawet Polką, a przyjechała na Dolny Śląsk w transporcie repatriacyjnym wraz z mamą i babcią. Tymczasem dokonując tego zabiegu literackiego w początku trzeciej dekady xxI w. wypada mi wyjaśnić to i wytłumaczyć wieloznaczność tytułu.

W omawianej serii wydawniczej redaktorzy postawili sobie za zadanie opublikować pamiętniki Sybiraków, które pod wieloma względami pozwolą spojrzeć na doświadczenie deportacji z województw wschodnich II RP w odmienny sposób niż inne pamiętniki o podobnej tematyce publikowane choćby we wspomnianej wcześniej serii wydawniczej „Biblioteka Zesłańca”. Jednakże od tego, jak zostaną opracowane takie pamiętniki, będzie zależało ich recepcja i oddziaływanie na kolejne pokolenia czytelników. Wydawanie pisanych przez Sybiraków w latach 70. i 8o. xx w. pamiętników, adresowanych najczęściej do osób wychowanych (albo chociażby wykształconych) w PRL, znających przynajmniej w stopniu podstawowym język rosyjski, nie wymagało od autorów tłumaczenia licznych barbaryzmów, w które obfituje narracja każdego z omawianych tu pamiętników. Wiele realiów społecznych było znanych i zrozumiałych dla znacznej części mieszkańców PRL, dla których doświadczenie zesłania, repatriacji i obozów sowieckich było często 
doświadczeniem jeśli nie osobistym, to być może rodzinnym. Mam jednak wątpliwości co do tego, czy współczesny czytelnik pozostawiony bez kompetentnego wyjaśnienia redakcji, nie zniechęci się po lekturze kilku bardziej wymagających partii tekstu. Dla zdeterminowanego czytelnika zainteresowanego tematyką te pamiętniki będą jednak doskonałym uzupełnieniem ich wcześniej zdobytej wiedzy na temat polskiej Syberiady.

Godne odnotowania jest jeszcze to, że wszystkie tomy podserii zostały bogato zilustrowane. Redaktorzy wykonali ogromnej pracy, docierając do materiałów z archiwów rodzinnych autorów oraz źródeł ikonograficznych z Narodowego Archiwum Cyfrowego, biblioteki cyfrowej Polona oraz licznych innych archiwów i bibliotek. Każdy z tomów został też opatrzony indeksem i krótkim streszczeniem w języku angielskim.

W moim przekonaniu omawiana edycja sama w sobie stanowi pewną zachętę dla badaczy tematyki do pogłębionych kwerend w zbiorach AN ZG PTL we Wrocławiu. Natomiast dzięki wyszukiwarce elektronicznej powstałej w ramach tegoż projektu edycyjnego, a zawierającej krótki opis zawartości źródła, możliwe będzie precyzyjne wykonanie wstępnych kwerend i dokonanie wyboru niepublikowanych w „Bibliotece Zesłańca” źródeł rękopiśmiennych przez każdego badacza w zależności od indywidualnych potrzeb.

Wspomnienia te także stanowią z historycznego punktu widzenia bardzo ważne dopełnienie nagrań oral history, które dokumentowały doświadczenia polskich zesłańców, rejestrując je w formie nagrań w ostatniej dekadzie xx i pierwszych dekadach xxI w. Utrwaliły one bowiem wspomnienia pokolenia, które odeszło, nim podjęto inicjatywy społeczne spisywania wspomnień na dużą skalę. Ich zestawienie z nagranymi wspomnieniami znacznie wzbogaci nasz warsztat badawczy i pozwoli na jego nieustanne doskonalenie.

Omówiona seria wydawnicza jest więc niezwykle potrzebnym przedsięwzięciem naukowym, wykonanym z ogromnym namysłem i szacunkiem do autorów opracowywanych wspomnień o doświadczeniu zesłania i pobytu w łagrze. Zważywszy jednak na aspekt obywatelski wydawania takich źródeł, pozostaje jedynie żywić nadzieję, że redaktorzy rozważą rozszerzenie grona czytelników na kolejne pokolenia poprzez dodanie objaśnień dotyczących ważniejszych realiów życia całych pokoleń Polaków, którzy doświadczyli zesłania i repatriacji. 